\title{
Are Pre-Service Teachers Ready to Write Stories in the Sciences?
}

\author{
Martha Georgiou ${ }^{1}$, Katerina Ziogka², Lia Galani²
}

\author{
${ }^{1}$ Department of Biology, National and Kapodistrian University of Athens, GREECE \\ ${ }^{2}$ Department of Primary Education, National and Kapodistrian University of Athens, GREECE \\ *Corresponding Author: martgeor@biol.uoa.gr
}

Citation: Georgiou, M., Ziogka, K., \& Galani, L. (2020). Are pre-service teachers ready to write stories in the sciences? Interdisciplinary Journal of Environmental and Science Education, 16(4), e2220. https://doi.org/ 10.29333/ijese/8421

\begin{abstract}
ARTICLE INFO
ABSTRACT

Received:

27 May 2020

Accepted:

13 July 2020

According to literature, science-based stories can not only trigger students' curiosity about scientific concepts but also increase their understanding of them as well as to facilitate the retention of information in students' memory. It is a common practice for elementary school teachers to create stories in order to teach several topics. To investigate the ability of pre-service teachers in Science story writing, we selected the topic of karst caves which it can be studied through many disciplines (i.e. Geography, Geology, Biology, Chemistry, Environmental education, Ecology) according to the Greek curriculum. Moreover, although karst caves are part of Greece's geological history, they are neither taught nor extensively mentioned in the Greek Primary and Secondary Education curricula. In this research, we examined whether Greek pre-service primary school teachers are able to create complete science-based stories about karst caves, by following the necessary didactic transposition of scientific concepts and the key elements in structure and plot of a such a story. For this purpose, we assessed by content analysis 100 pre-service teachers' written stories. The results revealed that most of the participants achieved to create sufficient stories in structure and plot, whereas they did not achieve to transpose the necessary scientific concepts that they had included in their writing.
\end{abstract}

Keywords: science-based stories, story writing, science education; Karst Caves, geography-geology, caves' ecosystem

\section{INTRODUCTION}

According to the literature narrating scientific stories is an appropriate teaching tool for all levels of education (McComas et al., 1999; Mavrikaki et al., 2012), while at the same time science-based stories can enhance students' interest, through effective and coherent content (Hadzigeorgiou, 2006). The narrative form of scientific concepts has the potential to arouse the curiosity of students, to increase their understanding and help them to remember more (Egan, 1989). The telling of a story is necessarily preceded by the creation of one. In ancient times, oral narratives (e.g. the Greek poet Homer) served to transfer historical, religious, cultural, and other information to the audience. All stories, even those not originally set down in written form, serve as a tool for learning and discovering about oneself and the world. They are tools for adopting and building knowledge (Martin et al. 2018).

Therefore, the process of creating or writing a story is an essential element in its effectiveness since, through a story, authors can share experiences, emotions and information. It is a powerful means of transferring new knowledge (Graham, MacArthur, \& Fitzgerald, 2013). Graham \& Perin (2007a) refer that the writing of a story followed by the telling of it has been shown to enhance learning outcomes not only in the social sciences, but also in the natural sciences, mathematics, arts, and foreign language learning. However, in order to achieve the learning goal of introducing new scientific concepts to students, an understandable and memorable text should be written (Graham \& Hebert, 2010, 2011).

To create such a text of a scientific story, pre-service teachers will need to focus on the didactic transposition of scientific concepts, a process which requires the deconstruction and reconstruction of scientific knowledge so that the content will be appropriate in any educational level (Achiam, 2014).

Although much research has been conducted regarding storytelling's efficacy in science teaching (Egan, 1989; 
Postman, 1989) and learning (Millar \& Osborne, 1998; Rowcliffe, 2004), regarding teachers' skills in storytelling (Kubli, 2001; Hammer, 1999; Romanelli, 2016) or even students' ability in telling stories (Işıtan \& Doğan, 2015; Wightman \& Roney, 2013), there is only a few research about story writing and specifically in story writing by teachers in order to use these stories to instruct their students. Hence, Corni at al. (2014) used Physics concepts as a case study to investigate in which extent story writing can be a tool for teachers' professional development, whereas Frisch (2010) conducted research to verify whether pre-service teachers were able to create scientific stories with Physics elements incorporated, appropriate for Physics instruction. Consequently, story writing by pre-service and in service teachers should be examined more in order for science educators to provide them with appropriate guidelines for creating stories, appropriate in science teaching.

In this context, our research aimed to investigate whether pre-service teachers were able to create a complete science-based stories, and whether or not a didactic transposition of scientific concepts was achieved through their stories.

\section{THEORETICAL BACKGROUND}

\section{Teaching Scientific Concepts through Science-Based Stories}

Using scientific stories has appeared as a teaching method since the beginning of mankind so that it can be seen as a timeless educational method (Mavrikaki \& Kapsala, 2012). According to Egan (1989), stories are used not only as a means of transferring knowledge and experience from generation to generation but also as a different method of teaching. They can evoke emotions that already hold an important place in one's memory, therefore facilitating the instillation of the associated information into the long-term memory (Mavrikaki \& Kapsala, 2012). Besides, stories are an ideal trigger for cultivating a person's imagination.

Science-based stories are seen as a valuable educational tool, since a person can interpret story's various elements according to his/her personal experience and knowledge about the way the world is constructed (Postman, 1989). For this reason, this method of teaching in science education has been suggested by many researchers: Millar and Osborne (1998) argue that stories can present science in a way that stimulates students' learning of scientific concepts by presenting them in a meaningful, consistent and memorable context. The development of students' curiosity and the increase of their sense of exploration and excitement about science should be included in the goals of the science curriculum.
Therefore, stories are a mean of achieving positive learning outcomes as long as they are relevant to the curriculum, while at the same time intriguing and exciting (Rowcliffe, 2004). Koening and Zorn (2002) promote stories' narratives as a method of linking theory and practice, and Abrahamson (1998) observes that students can better understand a piece of information when it is supported by specific examples. Furthermore, according to Walan (2019), stories can be used as a tool to provide students with different perspectives on an issue or concept. When using science-based stories in science teaching, many educational goals are achieved, as it can contribute to the evolution of science teaching, improvement of classroom atmosphere, and the development of a positive attitude towards science (Kokkotas et al., 2010).

Hence, science-based stories can be a part of many different teaching strategies: None of the researchers cited above claim that this kind of stories are the only way to teach science, but they point out that a good teacher uses many educational strategies, and that is one of them. As Boström (2006) argues, scientific stories can be used in context-based teaching approaches, problem-solving, inquiry-based learning, as well as with practical activities or research. According to Rowcliffe (2004), they can be used in science education to present a scientific problem, to explain a complicated process, or even to incorporate scientific issues into everyday life. According to Green (2004), scientific stories are a dynamic way of organizing and disseminating information relevant to both the students' life and the environment in which they act. An inspirational story can become a trigger for generating an educator's interest in teaching a subject, thereby stimulating the students' imagination (Zazkis \& Liljedahl, 2009).

Nevertheless, writing a science-based story for teaching purpose is not always a simple procedure. There are key elements that teachers should keep in mind when creating such stories. Hence, according to Zazkis and Liljedahl (2009), any scientific story used in the classroom should include the following elements (i) a plot, (ii) the human factor, (iii) pose a question, (iv) images and (v) humor. The aim is not only for teachers to create fascinating stories on the subject that students should be taught, but rather the way teachers find to turn each piece of the curriculum into a pole of interest for students. The scientific information presented in the story must not distorted, as to preserve the educational character of the final result. However, imaginary elements which do not affect the reality of the scientific concept may be included. (Zazkis \& Liljedahl, 2009).

On the other hand, the structure of a story plays a significant role. Consequently, the beginning of the story is a crucial stage as it should both arouse the interest of 
students, and stimulate their imagination and ingenuity. The main part of the story should contain the learning goals, so the ideas must be clear and well structured. Moreover, the end of the story should be interesting and give a sense of completeness and an appropriate conclusion (Hadjigeorgiou, 2006).

Combining all the above elements, Bruner (1996) refers to Aristotle's emphasis that: (i) a story should be of such size and extent that it will be easy to retain in one's memory, (ii) The content of the story should refer to a comprehensive act and should be structured in three parts: the beginning, the main body, and the epilogue, and (iii) the most critical elements of a story are its plot, its sequence of events, and its actions. Based on the Aristotelian concept of adventure, Bruner (1996) has summarized the archetypal structure of all stories as follows: In the beginning, a typical situation is presented. It followed by a crisis or problem that overturns the normal situation, which in turn is followed by the hero's efforts to restore its regularity, and in the end, a new normal state of affairs has been established. According to Klassen (2006), the structure of stories promotes the activation of the learning process: Writing of a scientific story and then telling it, encourages active learning through the formulation of hypotheses and explanations by students.

In addition to features such as plot, structure, etc., the didactic transposition of scientific concepts plays a vital role in science-based stories when these stories are designed for teaching purposes with the goal of the acquisition and understanding of the concept by the students. Consequently, the didactic transposition of the target scientific concept must always be kept in mind by pre-service teachers writing such stories. Specifically, the didactic transposition of a scientific concept in order to integrate it into an instructive and enjoyable story requires more than a simple narration of events (Hadjigeorgiou, 2006).

According to Chevallard (1985), a didactic transposition is defined as the set of modifications that the content of scientific knowledge undergoes in order to become school knowledge. Develay (1992) discerned three stages of didactic transposition: i) scientific knowledge in taught knowledge (e.g. educational material), ii) taught knowledge in teachers' perceptions and activities, and finally iii) taught knowledge in student's knowledge. Thus, the content of didactic transposition of scientific knowledge into school knowledge is, in fact, a construction with autonomous characteristics and peculiarities, rather than merely a simplification of scientific knowledge (Koliopoulos, 2006). The autonomy of school scientific knowledge arises from the social needs that affect the teaching purposes and objectives of the natural sciences, intending to cultivate students' scientific knowledge or the acquisition of specialized technical knowledge by students (Tiberghien, 1989). The main elements of didactic transposition are decontextualization (i.e. the extraction of scientific knowledge from the scientific environment in which it was "born") and recontextualization (i.e. the formation of an educational explanation of scientific knowledge). In fact, in the process of deconstruction, the formation of educational material leads to the reconstruction of scientific knowledge. Hence, a new, artificial epistemological framework is created that concerns the conceptual scientific content (Johsua \& Dupin, 1993). In short, the process of didactic transposition facilitates the study and analysis of scientific concepts and, more specifically, in the modifications of scientific knowledge from its original scientific framework until it becomes transformed into school knowledge (Vellopoulou \& Ravanis, 2010).

Through the process of didactic transposition, teachers should "transform" all the scientific knowledge that primary school students have to learn into a way that is easy for them to understand. The process of didactic transposition occurs not only whenever one person intends to teach scientific knowledge to another, but also in other contexts, such as in the media and/or museums (Clément, 2000). The process of didactic transposition focuses on the adaptation of scientific knowledge - and especially on its recontextualization - in order to be understandable to the target audience (Achiam, 2014).

Interdisciplinary scientific concepts provide an excellent context for science-based story writing, as there are multidimensional aspects of the embedded scientific issue, that allow the writer to include all the key elements mentioned above. Karst caves are governed by this interdisciplinarity and are therefore an ideal case for the development of scientific stories.

\section{The Concept of Karst Caves in Education and Greek Curricula}

According to the literature, karst caves are precious natural resources (Pipan \& Culver, 2013) of great importance (i.e. geological, geographical, biological, environmental, historical, touristic and cultural)

Concepts such as "karst caves' formation", "the life in darkness", "caves connection to our knowledge of human's ancestors" (Sherwood \& Simek, 2001), "pre-historical caves' art", "sustainability of caves' environment", may trigger students' curiosity about Science.

Moreover, the case of karst caves is a great opportunity for the Science teacher to make interdisciplinary connections between sciences as it is a topic which coincides with several scientific fields i.e., Geography, Geology, Biology, Chemistry and their aspects (Figure 1). The above 
mentioned make the karst cave topic a fascinating topic to teach through science-based stories.

As we noticed in the literature review of this paper, a teacher in order to write a good scientific story, one of the things he/she should consider is the literature about students' misconceptions. Our study of international literature brought to light the lack of both scientific research on students' misconceptions about karst caves, as well as teaching interventions on this topic. Francek (2013), refers that although $10-15 \%$ of the Earth's surface is covered by karst systems, there is little research on the misconceptions of primary, secondary and university students related to karst geomorphology. However, some students are curious about the cave landforms and the way they were formed. According to the researcher, this phenomenon is due to the fact that karst landforms do not explode, move, or appear in epic cinematic films, such as do volcanoes, earthquakes and dinosaurs.

Thus, based on the literature review, misconceptions could be categorized into two categories.

The first category relates to students' misconceptions about the hydrogeological characteristics of a karst system:

- The substrate is compact and free of gaps (Kastning \& Kastning, 1999).

- All sinks were formed in a catastrophic way (Kastning \& Kastning, 1999).

- The characteristics of a karst system are also imprinted on the surface of the ground (Kastning \&
Kastning, 1999).

- All the caves were formed by erosion (Kastning \& Kastning, 1999).

- Caves and rocks have the same age (Kastning \& Kastning, 1999).

- Karst cavities in limestone were formed by animals or human intervention (Environmental Systems Texas, 2011).

- The lack of a karst cave indicates little or no karst growth (Kastning \& Kastning, 1999).

- Caves extend deep into the interior of the Earth (Kirkby, 2008).

The second category contains students' misconceptions about the role of water in a karst system:

- Water does not create sinks but passes through them as they are already there (Kastning \& Kastning, 1999).

- The flow of groundwater into a karst system is simple and direct (Kastning \& Kastning, 1999).

- Pollutants that enter into a karst system remain there without moving (Kastning \& Kastning, 1999).

- Water from Karst springs is pure (Kastning \& Kastning, 1999).

- All the aquifers, independently from the rock which they pierce, have the same characteristics (Environmental Systems Texas, 2011).

- Water in karst systems comes from the sea (Environmental Systems Texas, 2011).

- Groundwater exists mainly as huge underground

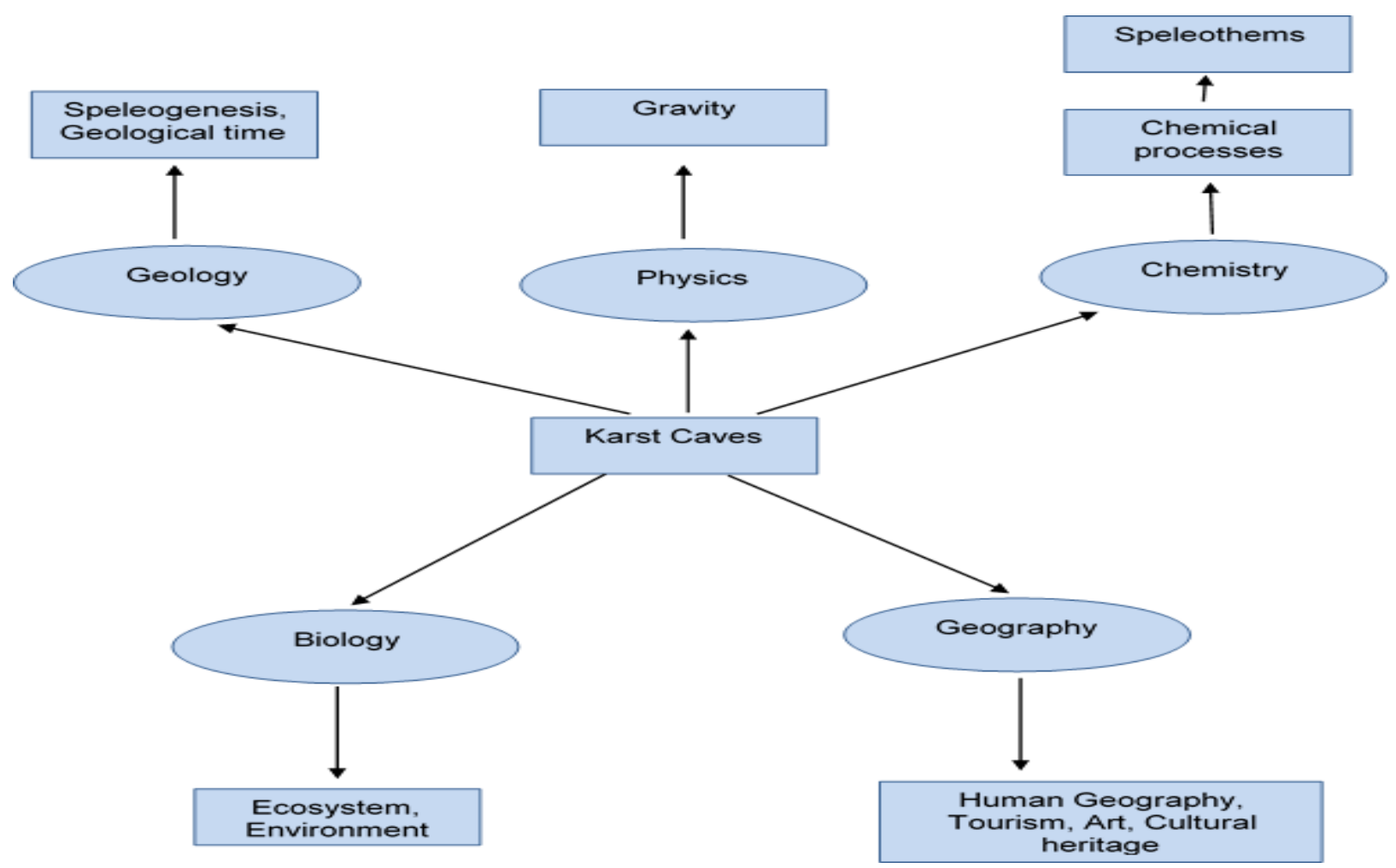

Figure 1. Karst caves' interdisciplinarity 
rivers, lakes and seas. (Kirkby, 2008).

- Groundwater and spring waters are clean, as they are naturally filtered by the aquifers (Kirby, 2008).

Focusing on Greek education we noticed that although Greece's geological past justifies the existence of many karst caves in Greece, the limited presence of the concept of karst caves in typical education (Greek curricula and textbooks), is remarkable. Little information related to them is also provided through Photodentro, the National Repository of Educational Content for Primary and Secondary Education (photodentro.edu.gr). Consequently, all the above make clear that if teachers in Greek schools choose to teach karst caves to their students, then they have to create their own teaching material as there is no sufficient accompanying material. Hence, it is probable that they could lead themselves to write science-based stories about karst caves.

After reviewing the existing literature and taking into account (a) the efficacy of science-based stories in science teaching, (b) the reported students' misconceptions about karst caves, and (c) the limited references of karst caves' concept in the Greek Primary and Secondary School curricula, our research team decided to study the ability of pre-service teachers to create a science-based story about karst caves which would provide students with school knowledge about the ecological, environmental and cultural dimension of the caves. Consequently, in this context, basic information such as the definition of karst caves, the process of speleogenesis, the types of cave decoration / speleothems, the organisms found in a karst cave, and ways of protecting the caves were expected to be included in the stories. To meet these goals, the following research questions that arose were:

- Are Greek pre-service teachers able to incorporate all the target concepts related to karst caves into a scientific story for elementary school students?

- Are Greek pre-service teachers able to transpose the target concepts in order to use them in their science-based story?

- Are Greek pre-service teachers able to write an imaginative story following the structural requirements for the genre?

\section{METHODOLOGY}

To give answers to the previous questions, we designed and conducted our qualitative research aiming to evaluate science-based stories about the topic of karst caves written by Greek pre-service teachers.

\section{Participants}

The research population consisted of 100 pre-service teachers of the Department of Primary Education of the National and Kapodistrian University of Athens. The sample emerged after systematic sampling of a pre-service teachers' pool of 400 people. The research was conducted in the context of the compulsory course "Science III: Geography". It is important to mention that participants in the second year of bachelor's studies had attended the compulsory courses Science I: Physics and Science II: Biology). Moreover, as part of the Department of Primary Education curriculum, the participants had previously attended courses directly connected to storytelling and story writing, such as "Literature", "The Fairy Tale and Myth in Education", "Pedagogy of Literature", "Literature Teaching: Theory and Act", and they had successfully performed on the semester tests.

\section{Research Designing}

The duration of our research was approximately two months (from November 2019 to December 2019). Within this time frame, pre-service teachers were divided into groups of 20, with each group coming into contact with the researchers separately.

Each group meeting started with a three-hour session, which served as an initial orientation about the scientific concepts related to karst caves. At this time, the researchers provided the pre-service teachers/participants with specially selected educational material containing information about karst caves, so as to overcome the possible obstacle of participants' not having the necessary knowledge to complete the task. This accompanying material had been prepared, taking into consideration all the misconceptions recorded in literature. More specifically, the educational material consisted of two parts. The first part of the educational material was a document with all the relevant concepts and information about karst caves. In the second part, the pre-service teachers had the opportunity to explore five karst caves in different continents through the tools of Google Earth. The selection of these particular five karst caves was not accidental, as criteria for their selection were their location, their geological, geographic, biological and archaeological interest, their ecosystem, as well as their environmental, touristic and cultural heritage value. Furthermore, each of the five karst caves provided examples of or offered opportunities for the development of specific scientific concepts, such as definition, speleogenesis, cave decoration / speleothems, organisms that exist within a karst cave, and ways to protect the ecosystem of a cave.

Once ideas had been generated, the story writing process, which lasted for about two hours, began. The pre-service teachers were asked to write a story suitable for elementary school students, in which they had to 
Table 1. Focal scientific content of story: Organisms found in a karst cave

\begin{tabular}{lll}
\hline Main categories & Subcategories & Subcategories' findings \\
\hline Integration of scientific concept & Use of scientific vocabulary & Scientific inaccuracies \\
& & Misconceptions \\
& Use of didactic transposition & Scientific inaccuracies \\
Non integration of scientific concept & & Misconceptions \\
\hline
\end{tabular}

Table 2. Focal scientific content of story: Problems affecting karst caves and protection of them

\begin{tabular}{ll}
\hline Main categories & Subcategories \\
\hline $\begin{array}{l}\text { Integration of scientific concept: Problems affecting } \\
\text { karst caves' }\end{array}$ & Green disease \\
& $\begin{array}{l}\text { Industrial waste } \\
\text { Visitor garbage }\end{array}$ \\
Non integration of karst caves' problems & \\
Integration of karst cave protection & Avoidance of flash and warm lighting \\
& Management of industrial waste \\
& Avoidance of garbage disposal by visitors
\end{tabular}

Non integration of karst cave protection

incorporate and transpose the above scientific concepts into a comprehensible and imaginative educational tool for teaching a lesson on karst caves in a future class. To ensure anonymity and avoid potential bias, each participant was assigned their random number to be used when submitting their written work.

\section{Data Collection and Analysis}

At the end of the two-hour writing session, the researchers collected the participants' stories in order to analyze them through content analysis. Content analysis was chosen due to the fact that it covers the entire research process. An important step in analyzing the content of participants' stories was to determine the subject of each story, which was performed through the search and identification of the sources of analysis. In order to determine the unit of analysis, e.g. word or sentence or paragraph, etc., the material was indexed (Duvenger, 1978). Subsequently, the analysis categories were defined as follows: Main category (i.e. the integration of the scientific content which was the focus of the story), and subcategories (i.e. (i) use of relevant scientific vocabulary and facts, (ii) use of transposition, (iii) inaccuracies or misconceptions, which results were then interpreted (Cohen et al., 2008). Table 1 and 2 present examples of the analysis categories concerning the scientific part of the stories. In Table 1 under the title "Organisms found in a karst cave" the two main categories which researchers sought for/to, were the Integration / non integration of scientific concept. The category of integration was divided in two subcategories: a) Use of scientific vocabulary (ie. troglobites, troglophiles, trogloxenes, etc.) and b) Use of didactic transposition (i.e. according to the development of the students). We also included Scientific inaccuracies and Misconceptions (third column "Subcategories' findings) to provide a clearer analysis of the participants' written stories. In Table 2 under the title "Focal scientific content of story: Problems affecting karst caves and protection of them" researchers focused on two topics. The first one deals with the Integration / non integration of the problems affecting karst caves and the second with the Integration / non integration of karst caves protection. In the category of the Integration of scientific concept: Problems affecting karst caves' the subcategories found were a) Green disease, b) Industrial waste, c) Visitor garbage, while in cave's protection, some of the topics found were a) Avoidance of flash and warm lighting b) Management of industrial waste c) Avoidance of garbage disposal by visitors.

As previously mentioned, it was important for our 
research to check not only the content of the stories, but also their structure, if any (i.e., whether the story has a beginning, the main body, and a conclusion), the type of plot (i.e. is the story interesting/static/tedious), the use of narrative methods, and the technical aspects of the story (i.e. the use of anthropomorphism, the use of pictures in narration, the use of personalization, the use of "wise" characters in order to get answers) (see Table 3).

Finally, the analysis was performed with the aid of the IBM statistical program (c) SPSS Statistics 23 by two coders who processed the data separately. Initially, the agreement rate of the coders was $89 \%$, and after an extended discussion, the agreement rate was improved to $94.5 \%$.

\section{RESULTS OF THE ANALYSIS OF THE SCIENCE- BASED STORIES}

The stories written by the 100 pre-service teachers were analyzed, and the results relating to their ability to integrate and transpose the scientific concepts related to karst caves into an imaginative, science-based story were recorded. The results of the analysis appear in the Tables below (see Tables 4 - 9) organized according to each scientific concept. After each table there are corresponding examples.

In Table 4 we can notice that most of the participants included the definition of a karst cave in their stories $(\mathrm{N}=$ 92) but only a small percentage of them achieved to provide an appropriate didactic transposition (28.3\%).

Some examples of the didactic transposition achieved by the pre-science teachers are the following:

Gianna: “... then boy's mother said that the caves are located underground, inside the earth, and have dimensions such that one man can enter ...",

Flora: "... our world is called a cave, as we know ... but do you know that it is a natural cavity inside the earth? And how can anybody enter? ".

Examples of scientific inaccuracies and misconceptions are the following:

Table 3. Story writing structure

\begin{tabular}{ll}
\hline Main structure & Subcategories \\
\hline Following the structure & Plot (Interesting / Static / Tedious) \\
Non following the structure & Anthropomorphism \\
Story elements & Pictures \\
& Personalization \\
& Similes \\
& Easy approach to questions - answers or wise human / animal / cave
\end{tabular}

Table 4. Scientific definition of karst caves in pre-service teachers' written stories

\begin{tabular}{|c|c|c|c|c|c|}
\hline Main categories & $\begin{array}{l}\text { Number }(\mathrm{N}) \\
\text { of stories and } \\
\text { percentage (\%) } \\
\text { in a total of } 100 \\
\text { stories selected }\end{array}$ & Subcategories & $\begin{array}{l}\text { Number }(\mathrm{N}) \\
\text { of stories and } \\
\text { percentage }(\%)\end{array}$ & $\begin{array}{l}\text { Subcategories' } \\
\text { findings }\end{array}$ & $\begin{array}{l}\text { Number }(\mathrm{N}) \text { of } \\
\text { subcategories' } \\
\text { findings and } \\
\text { percentage (\%) }\end{array}$ \\
\hline \multirow{4}{*}{$\begin{array}{l}\text { Integration of } \\
\text { the scientific } \\
\text { definition of karst } \\
\text { caves }\end{array}$} & \multirow[t]{4}{*}{$\mathrm{N}=92,92 \%$} & \multirow{2}{*}{$\begin{array}{l}\text { Use of the } \\
\text { scientific } \\
\text { vocabulary }\end{array}$} & \multirow[t]{2}{*}{$\mathrm{N}=66,71.7 \%$} & $\begin{array}{l}\text { Scientific } \\
\text { inaccuracies }\end{array}$ & $\mathrm{N}=1,1.5 \%$ \\
\hline & & & & Misconceptions & $\mathrm{N}=0,0 \%$ \\
\hline & & \multirow[t]{2}{*}{$\begin{array}{l}\text { Use of the didactic } \\
\text { transposition }\end{array}$} & \multirow[t]{2}{*}{$N=26,28.3 \%$} & $\begin{array}{l}\text { Scientific } \\
\text { inaccuracies }\end{array}$ & $N=3,11.5 \%$ \\
\hline & & & & Misconceptions & $N=4,15.4 \%$ \\
\hline
\end{tabular}

Non-integration $\quad \mathrm{N}=8,8 \%$

of the scientific

definition 
Table 5. The process of speleogenesis in pre-service teachers' written stories

\begin{tabular}{|c|c|c|c|c|c|}
\hline Main categories & $\begin{array}{l}\text { Number }(\mathrm{N}) \\
\text { of stories and } \\
\text { percentage }(\%) \\
\text { in a total of } 100 \\
\text { stories selected }\end{array}$ & Subcategories & $\begin{array}{l}\text { Number }(\mathrm{N}) \\
\text { of stories and } \\
\text { percentage }(\%)\end{array}$ & $\begin{array}{l}\text { Subcategories' } \\
\text { findings }\end{array}$ & $\begin{array}{l}\text { Number }(\mathrm{N}) \text { of } \\
\text { subcategories' } \\
\text { findings and } \\
\text { percentage }(\%)\end{array}$ \\
\hline \multirow{4}{*}{$\begin{array}{l}\text { Integration of } \\
\text { the process of } \\
\text { speleogenesis }\end{array}$} & \multirow[t]{4}{*}{$\mathrm{N}_{\mathrm{A} 1}=94,94 \%$} & \multirow{2}{*}{$\begin{array}{l}\text { Use of the } \\
\text { scientific } \\
\text { vocabulary }\end{array}$} & \multirow[t]{2}{*}{$\mathrm{N}_{\mathrm{B} 1}=82,87.2 \%$} & $\begin{array}{l}\text { Scientific } \\
\text { inaccuracies }\end{array}$ & $\mathrm{N}_{\mathrm{C} 1}=2,2.4 \%$ \\
\hline & & & & Misconceptions & $\mathrm{N}_{\mathrm{c} 2}=3,3.7 \%$ \\
\hline & & \multirow[t]{2}{*}{$\begin{array}{l}\text { Use of the didactic } \\
\text { transposition }\end{array}$} & \multirow[t]{2}{*}{$\mathrm{N}_{\mathrm{B} 2}=12,12.8 \%$} & $\begin{array}{l}\text { Scientific } \\
\text { inaccuracies }\end{array}$ & $\mathrm{N}_{\mathrm{C} 3}=5,41.7 \%$ \\
\hline & & & & Misconceptions & $\mathrm{N}_{\mathrm{C} 4}=7,58.3 \%$ \\
\hline $\begin{array}{l}\text { Non-integration } \\
\text { of the process of } \\
\text { speleogenesis }\end{array}$ & $\mathrm{N}_{\mathrm{A} 2}=6,6 \%$ & & & & \\
\hline
\end{tabular}

Table 6. Speleothems in pre-service teachers' written stories

\begin{tabular}{llllll}
\hline Main categories & $\begin{array}{l}\text { Number }(\mathrm{N}) \\
\text { of stories and } \\
\text { percentage }(\%) \\
\text { in a total of } 100 \\
\text { stories selected }\end{array}$ & Subcategories & $\begin{array}{l}\text { Number }(\mathrm{N}) \\
\text { of stories and } \\
\text { percentage }(\%)\end{array}$ & $\begin{array}{l}\text { Subcategories' } \\
\text { findings }\end{array}$ & $\begin{array}{l}\text { Number }(\mathrm{N}) \text { of } \\
\text { subcategories' } \\
\text { findings and } \\
\text { percentage (\%) }\end{array}$ \\
\hline $\begin{array}{l}\text { Integration of } \\
\text { speleothemes }\end{array}$ & $\mathrm{N}=97,97 \%$ & $\begin{array}{l}\text { Use of the } \\
\text { scientific } \\
\text { vocabulary }\end{array}$ & $\mathrm{N}=72,74.2 \%$ & $\begin{array}{l}\text { Scientific } \\
\text { inaccuracies }\end{array}$ & $\mathrm{N}=1,1.4 \%$ \\
& & $\begin{array}{l}\text { Use of the didactic } \\
\text { transposition }\end{array}$ & $\mathrm{N}=25,25.8 \%$ & $\begin{array}{l}\text { Misconceptions } \\
\text { inaccuracies }\end{array}$ & $\mathrm{N}=1,1.4 \%$ \\
& & & Misconceptions & $\mathrm{N}=5,20 \%$
\end{tabular}

Non-integration of $\quad \mathrm{N}=3,3 \%$

speleothemes

Christos: "... a cave is every natural opening inside the earth ..."

Martha: “... with his magic rod, the magician formed a huge pit on the surface of the Earth to live there himself and do his magic ...".

Table 5 shows pre-service teachers' performance in referring to speleogenesis process. Most of them (94) built their stories integrating the process of speleogenesis and using the corresponding scientific vocabulary (82), but only 12 of them transposed the phenomenon and even in this case they could not avoid scientific inaccuracies (5) or misconceptions (7).

Indicative examples about speleogenesis:

Katerina: “...As the rainwater kissed the fallen leaves, a child, called Carbonic Acid, pierced the Earth. He dug a great passage to go down, and when he couldn't dig down any more he built a very remarkable palace. But as the years went by, he began to get bored underground and followed his friends the rivers, lakes, and springs, to a long journey to the blue...",

Eirini.: "He (the carbon dioxide) decided to let a drop of rain gently pull him to the ground. He became friend with a molecule of water and as a result carbonic acid was created ... They rolled together through the crack of a ..., Hugging each other tightly, they crossed a long corridor and reached a large hall ... the famous cave...”.

Indicative examples of scientific inaccuracies and misconceptions:

Renia: “... carbonic acid eats limestone rocks ...”,

Tasos: “... the rainwater began to pierce the mountain ...",

Dimitris: “... water converts carbon dioxide into acid ...”.

Table 6 summarizes the numbers of participants' stories 
Table 7. Organisms found in a karst cave in pre-service teachers' written stories

\begin{tabular}{|c|c|c|c|c|c|}
\hline Main categories & $\begin{array}{l}\text { Number } \\
\text { (N) of } \\
\text { stories and }\end{array}$ & Subcategories & $\begin{array}{l}\text { Number }(\mathrm{N}) \\
\text { of stories and } \\
\text { percentage (\%) }\end{array}$ & $\begin{array}{l}\text { Subcategories' } \\
\text { findings }\end{array}$ & $\begin{array}{l}\text { Number }(\mathrm{N}) \text { of } \\
\text { subcategories' findings and } \\
\text { percentage }(\%)\end{array}$ \\
\hline \multirow{4}{*}{$\begin{array}{l}\text { Integration of } \\
\text { organisms found in a } \\
\text { karst cave }\end{array}$} & \multirow[t]{4}{*}{$N=96,96 \%$} & $\begin{array}{l}\text { Use of the scientific } \\
\text { vocabulary }\end{array}$ & $N=83$ & $\begin{array}{l}\text { Scientific } \\
\text { inaccuracies }\end{array}$ & $\mathrm{N}=1,1.2 \%$ \\
\hline & & $\begin{array}{l}\text { - Visitors }\left(\mathrm{N}_{1)}\right. \\
\text { - Trogloxens }\left(\mathrm{N}_{2}\right) \\
\text { - Troglophiles }\left(\mathrm{N}_{3}\right) \\
\text { - Troglobites }\left(\mathrm{N}_{4}\right)\end{array}$ & $\begin{array}{l}N_{1}=46-47.9 \% \\
N_{2}=74-77.1 \% \\
N_{3}=77-80.2 \% \\
N_{4}=83-86.5 \%\end{array}$ & Misconceptions & $N=2,2.4 \%$ \\
\hline & & $\begin{array}{l}\text { Use of the didactic } \\
\text { transposition }\end{array}$ & $N=50$ & $\begin{array}{l}\text { Scientific } \\
\text { inaccuracies }\end{array}$ & $\mathrm{N}=1,2 \%$ \\
\hline & & $\begin{array}{l}\text { - Visitors }\left(\mathrm{N}_{1)}\right. \\
\text { - Trogloxens }\left(\mathrm{N}_{2}\right) \\
\text { - Troglophiles }\left(\mathrm{N}_{3}\right) \\
\text { Troglobites }\left(\mathrm{N}_{4}\right)\end{array}$ & $\begin{array}{l}\mathrm{N}_{1}=50-53.8 \% \\
\mathrm{~N}_{2}=22-22.9 \% \\
\mathrm{~N}_{3}=19-19.8 \% \\
\mathrm{~N}_{4}=13-13.5 \%\end{array}$ & Misconceptions & $N=5,10 \%$ \\
\hline
\end{tabular}

Non-integration of

organisms found in a $\mathrm{N}=4,4 \%$

karst cave

Note: More than one kind of organisms were noted in pre-service teachers' written stories.

relating the concept of speleothemes. Once again, almost all the stories (97) contain the concept of the speleothemes but we did not identify the necessary didactic transposition with a few exceptions (25) of which only the half were clear of scientific inaccuracies and misconceptions.

Indicative examples about speleothemes:

Mary: “...he saw stalactites hanging as crystals from the ceiling... Just below them, the stalagmites... They were trying to reach each other and form a unique column ...",

Fenia: "... a big tear hangs from the roof of the cave, and he tries to get down to meet his little brother. Stalactite and stalagmite are sad and have been trying for centuries to meet....",

Indicative examples of the scientific inaccuracies and misconceptions:

Lena: “... the stalactites hang from the ceiling and are made of many drops of water ...",

Takis: "... the stalactites hang from the ceiling and the stalagmites grow on the floor ...".

Analyzing the content of the stories we found that frequently more than one kind of organism were included in the story. More specifically, troglophiles were found in the majority of stories ( $\mathrm{N}_{4}=83-86.6 \%$ ) while visitors were less present $\left(\mathrm{N}_{1}=46\right)$. On the other hand, it was encouraging that in quite a number of stories $(\mathrm{N}=50)$ the different kinds of organisms were appropriately transposed. In Table 7 all corresponding information is presented.

Indicative examples of living organisms of the karst caves (karst caves' ecosystem):

Maria: “...there are bats living in the cave but find their food outside ... Look there! Those whitish spiders have adapted so well here that they do not have to go out... Hey, frog! Have you lost your way again?",

Anna: "... there was only one thing that she will miss... Her friends in the cave: the bats, which welcomed her at the entrance, the quit but friendly spiders and all the other creatures in the depths of cave which live in a world with no light...".

Some examples of scientific inaccuracies and misconceptions:

Dora: “... looking around, the two friends saw bats, only bats ...",

Fotini: “... the cave was inhabited by creatures other than the elf ...".

In Table 8 are shown all the problems, affecting karst caves and the ways of their protection, that were captured in the written stories.

Indicative examples of environmental issues related to karst caves: 
Table 8. Problems affecting karst caves and their protection in pre-service teachers' written stories

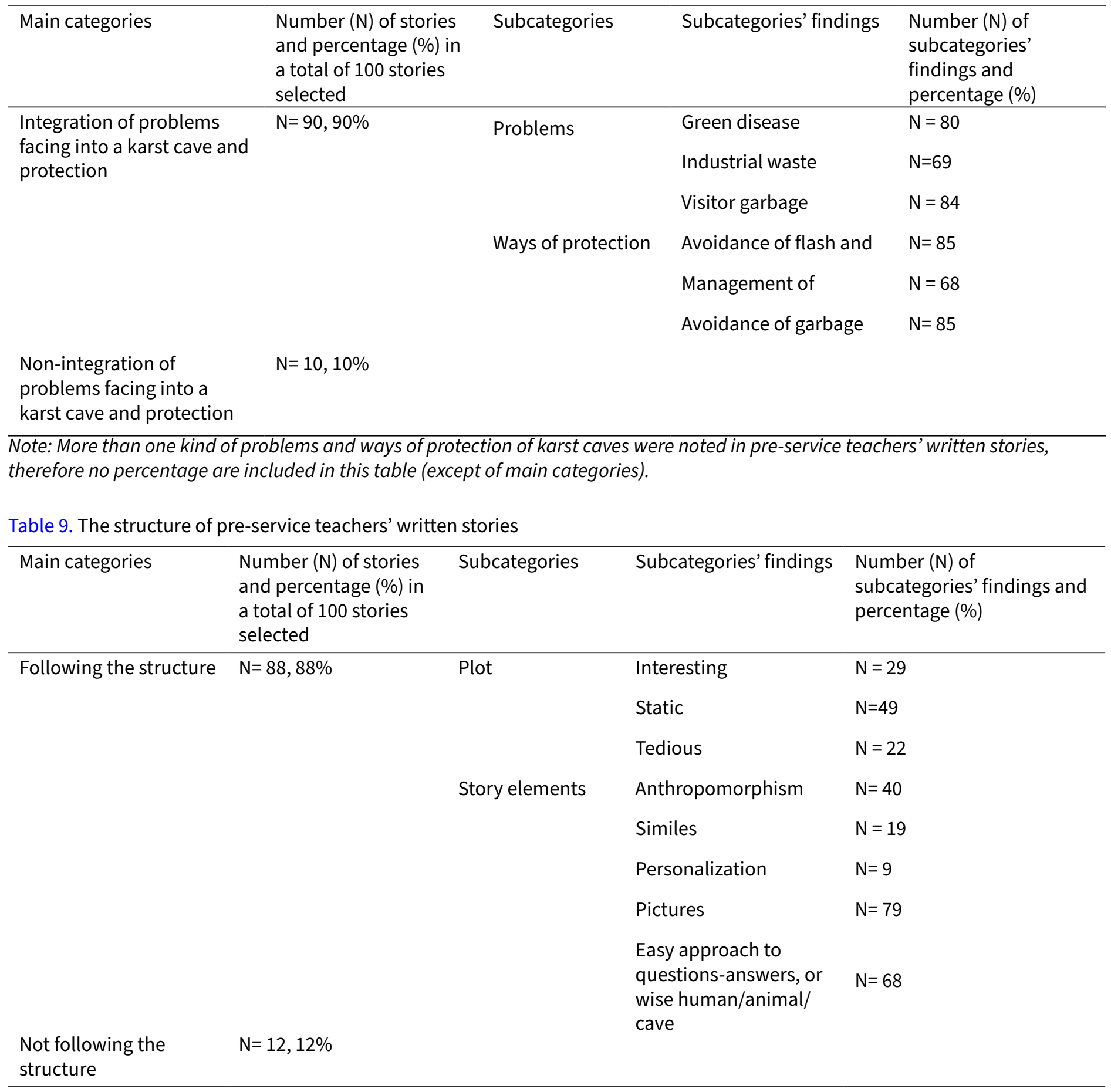

Roula: “...today karst caves are at risk from visitors' garbage, industrial waste, and green disease, which caused by heat resulting from the use of lighting and camera flashes..."

Mirto: “...future visitors: Please never place too many yellow lights in our cave and do not constantly take pictures of us by using your cameras. We are not used to it and we don't like it... And please, don't leave trash behind you! After all, it's not polite. Respect our home as if it were yours!...".
As it is shown in Table 9, most of the participants (88\%) followed the appropriate structure to build their stories. Nevertheless, the plot of the half of these stories was static and only 29 stories had interesting plot. Anthropomorphism (40 stories), pictures (79) and wise human/animal/cave in order to get easy answers (68) were mostly used in the stories.

In summary, the general picture emerging from the pre-science teacher's stories showed that while a large percentage managed to incorporate all the scientific concepts into them, this was accomplished without 
any particular didactic transposition or at least without successful didactic transposition in terms of absence of scientific inaccuracies and misconceptions.

\section{DISCUSSION AND CONCLUSION}

In this research, we attempted the analysis of the science-based stories that pre-service teachers were asked to create for primary school students about karst caves. By analyzing their science-based stories, we focused on two issues: the transposition of scientific concepts, and the development of participants' skills to create teaching tools (written narratives, in our case), which could be used in the teaching process.

As mentioned above, karst caves are not taught extensively in Greece at any educational level. The analysis of pre-service teachers' ability to transpose scientific concepts is not very encouraging. More specifically, $71.7 \%$ of the pre-service teachers used scientific vocabulary to define karst caves, $87.2 \%$ for the speleogenesis process and $74.2 \%$ for speleothems. As regards the organisms that exist in a karst cave, it was found that the use of scientific vocabulary was more significant for the groups of organisms that were described in strictly scientific terms in the teaching material they had been given. Thus, only $47.9 \%$ of the pre-service teachers used scientific vocabulary for visitor organisms while for troglophiles, trogloxenes and troglobites, the percentages were $77.1 \%, 80.2 \%$ and $86.5 \%$, respectively. One possible interpretation for the choice of scientific vocabulary the teachers used is that when the concepts had been presented in the didactic material and discussed, there had not been sufficient time for the teachers to become familiar enough with them in order to be able to transpose these concepts. On the other hand, according to the results of our study, pre-service teachers' science-based texts showed low percentages of scientific inaccuracies or misconceptions in the total of the 100 stories selected. The designing of the educational material, the research on scientific information via Google Earth were factors that may contributed to this positive result, which nevertheless was not enough to succeed didactic transposition as well since participants were limited to reproduce scientific concepts in their strict scientific form.

Every teacher is required to transpose scientific knowledge on a daily basis in order to communicate it to students. Therefore, the simple reproduction of scientific vocabulary, scientific definitions or processes gradually leads to memorization rather than critical thinking and understanding and is responsible for the low literacy observed in the natural sciences (Groves, 1995). Hence, since future teachers will directly be involved in the preparation of students and the development of their ability to manage scientific knowledge in order to participate in decision-making on socio-scientific issues of everyday life (Kolsto, 2001), writing science-based stories including all the key elements, will be very fruitful for their students/ future citizens.

Finally, the analysis of the results of the stories relating to the problems affecting a karst cave and their protection are particularly encouraging. The high rates of reference to these concepts indicate that it was an issue that pre-service teachers were aware of and obviously more familiar with. It is probable that environmental issues, approached through previous formal and/or non-formal education (Coertjens et al., 2010), in the context of their compulsory education in University or in school earlier, have provided positive results in involving in such concepts. The way in which pre-service teachers approached the protection of karst caves in their written narratives was remarkable: More than $50 \%$ approached the issue from the perspective of active citizens.

Concerning the structure of the stories, we observed that a high percentage of pre-service teachers have managed to maintain the principles of writing a story $(88 \%)$. This high percentage is likely to result from their involvement with the curriculum lessons directly related to literature, storytelling and story writing which they had attended and successfully performed. Besides, it is important to address the high rates of visualization and anthropomorphism which were used to visualize the story, as pupils are more likely to connect with specific concepts than abstract ones (Zazkis et al., 2009). Finally, the approach of communicating scientific knowledge easily but superficially by writing stories using scientific terms without didactically transposing them, as well as the small percentage of stories with interesting plots $(29 \%)$, raise the question as to whether, in the end, the traditional teaching model has been established in the consciousness of pre-service teachers, leading them to follow the established practice and without utilizing new and attractive teaching tools such as stories.

In summary, as our research results show, pre-service teachers are generally able to create a written narrative following the appropriate structure, but they find it difficult to incorporate concepts with which they are unfamiliar and mainly they had difficulty in didactic transposition, which of course is of great importance in science teaching. Consequently, it may be probable that more training on achieving didactic transposition is needed to be incorporated in their academic curriculum. Tasks as this one of our research could help in this direction. At the same time this kind of training could perhaps reduce the risk that older teaching models will be reproduced during the teaching intervention, resulting in a learning 
environment that is not very attractive, and in which students do not have an active role (Elmore, Peterson, \& McCarthy, 1996). Writing and later telling science-based stories in the educational process can be a powerful tool in a teacher's hands to design and implement a modern, attractive lesson but only if these science-based stories are created in an appropriate manner.

\section{LIMITATIONS}

The main limitation of this research is the inability to generalize the results for a larger population of pre-service teachers since it provides a limited number of participants (Yin, 1984). This limitation, however, does not diminish the value of the research but underlines the need for enlargement of the sample as to capture a more comprehensive image of the skills of Greek primary pre-service teachers in science education.

\section{REFERENCES}

Abrahamson, C. E. (1998). Storytelling as a pedagogical tool in higher education. Education, 118(3), 440-452.

Achiam, M. (2014). Didactic transposition: From theoretical notion to research programme. ESERA summer school, Kapadokya, Turkey, August 24, 29, 2014.

Boström, A. (2006). Sharing lived experience: How upper secondary school chemistry teachers and students use narratives to make chemistry more meaningful (Doctoral dissertation, Stockholm Institute of Education Press).

Bruner, J. S. (1996). The culture of education. Harvard University Press.

Chevallard, Y. (1985). Didactic transposition, the learned knowledge to knowledge taught. La pensée wild, Grenoble.

Coertjens, L., Boeve-de Pauw, J., De Maeyer, S., \& Van Petegem, P. (2010). Do schools make a difference in their students' environmental attitudes and awareness? Evidence from PISA 2006. International Journal of Science and Mathematics Education, 8(3), 497-522.

Cohen, L., Manion, L., \& Morrison, K. (2008). Methodology in education research (in Greek).

Corni, F., Giliberti, E., \& Fuchs, H. U. (2014). Student teachers writing science stories: A case study. In ESERA 2013 Conference-Science Education Research for Evidence-based Teaching and Coherence in Learning (pp. 2494-2505). ESERA.

Develay, M. (1992). De l'apprentissage à l'enseignement.[From learning to teaching]. Paris, ESF.

Egan, K. (1989). Teaching as story telling: An alternative approach to teaching and curriculum in the elementary school. University of Chicago Press.

Elmore, R. F., Peterson, P. L., \& McCarthey, S. J. (1996). Restructuring in the classroom: Teaching, learning, and school organization. Jossey-Bass Inc., Publishers, 350 Sansome Street, San Francisco, CA 94104; Web site: http://www. josseybass. com.

Francek, M. (2013). A compilation and review of over 500 geoscience misconceptions. International Journal of Science Ed- ucation, 35(1), 31-64.

Frisch, J. K. (2010). The stories they'd tell: pre-service elementary teachers writing stories to demonstrate physical science concepts. Journal of Science Teacher Education, 21(6), 703-722.

Graham, S., \& Perin, D. (2007a). What we know, what we still need to know: Teaching adolescents to write. Scientific Studies of Reading, 11(4), 313-335.

Graham, S., \& Hebert, M. (2010). Writing to read: Evidence for how writing can improve reading. Washington, DC: Alliance for Excellent Education.

Graham, S., \& Hebert, M. (2011). Writing to read: A meta-analysis of the impact of writing and writing instruction on reading. Harvard Educational Review, 81(4), 710-744.

Graham, S., MacArthur, C. A., \& Fitzgerald, J. (Eds.). (2013). Best practices in writing instruction. Guilford Press.

Green, M., C. (2004). Storytelling in teaching. Observer, 17(4): 37-38.

Groves, F. H. (1995). Science vocabulary load of selected secondary science textbooks. School Science and Mathematics, 95(5), 231-235.

Hadjigeorgiou, G. (2006). Towards a scientific education. Grigoris Publications.

Hamer, L. (1999). A folkloristic approach to understanding teachers as storytellers. International Journal of Qualitative Studies in Education, 12(4), 363-380.

Işıtan, S., \& Doğan, Ö. (2015). An Examination of 1st, 2nd and 3rd grade elementary school students' story-telling skills based on narrative analysis. Education \& Science, 40(177). 175-186.

Johsua, S., \& Dupin, J. J. (1993). Using “Modelling Analogies" to teach basic electricity: A critical analysis. In Learning Electricity and Electronics with Advanced Educational Technology (pp. 39-55). Springer, Berlin, Heidelberg.

Kastning, E. H., \& Kastning, K. M. (1999, October). Misconceptions about caves and karst: Common problems and educational solutions. In Proceedings of the 14th National Cave and Karst Management Symposium (pp. 99-107).

Kirkby, K. (2008). 'Easier to Address' Earth Science Misconceptions. Teaching Introductory Geoscience Courses in the 21st Century. Teach the Earth: the portal for Earth Education https://serc.carleton.edu/NAGTWorkshops/intro/misconception_list.html retrieved 30 March 2020.

Klassen, S. (2006). A theoretical framework for contextual science teaching. Interchange, 37(1-2), 31-62.

Koening, J. M., \& Zorn, C. R. (2002). Using storytelling as an approach to teaching and learning with diverse students. Journal of Nursing Education, 41(9), 393-399.

Kokkotas, P., Rizaki, A., \& Malamitsa, K. (2010). Storytelling as a strategy for understanding concepts of electricity and electromagnetism. Interchange, 41(4), 379-405.

Koliopoulos, D. (2006). Didactic subjects of natural sciences. Formation of knowledge acquired at school (in Greek). Metaixmio, Athens.

Kubli, F. (2001). Can the theory of narratives help science teachers be better storytellers?. In Science Education and Culture (pp. 179-183). Springer, Dordrecht.

Martin, G. (2018). Storytelling and narrative inquiry: Exploring research methodologies. In D. McGregor, J. Restoule \& R. Johnston (Eds.), Indigenous research: Theories, practices, and relationships. (pp. 187 - 199). Toronto: Canadian Schol- 
ars

McComas, K., \& Shanahan, J. (1999). Telling stories about global climate change: Measuring the impact of narratives on issue cycles. Communication Research, 26(1), 30-57.

Mavrikaki, E. \& Kapsala, N. (2014). Teaching biology by storytelling. In G. Katsiampoura (ed.), Scientific Cosmopolitanism and Local Cultures: Religions, Ideologies, Societies, Proceedings of the 5th International Conference of the European Society for the History of Science - 5ESHS (pp. 612-617). Athens. ISBN 978-960-98199-3-0.

Mavrikaki, E., Koumparou, H., Kyriakoudi, M., Papacharalampous, I., \& Trimandili, M. (2012). Greek secondary school students' views about biology. International Journal of Environmental and Science Education, 7(2), 217-232.

Millar, R. \& Osborne, J., F. (1998). Beyond 2000: Science Education for the Future. London: King's College London.

Pipan, T., \& Culver, D. (2013). Forty years of epikarst: what biology have we learned? International Journal of Speleology, 42(3), 5.

Postman, N. (1989). Learning by story. The Atlantic, 264(6), 119124.

Romanelli, F. (2016). Are great teachers great storytellers?. American Journal of Pharmaceutical Education, 80(6), 93.

Rowcliffe, S. (2004). Storytelling in science. School science review, 86(314), 121.

Sherwood, S. C., \& Simek, J. F. (2001). Introduction: Cave archaeology in the eastern Woodlands. Midcontinental Journal of Archaeology, 26(2), 135-137.

Tiberghien, G. (1989). Advances in cognitive science. Ellis Horwood Limited.

Vellopoulou, A., \& Ravanis, K. (2010). A methodological tool for approaching the didactic transposition of the natural sciences in kindergarten school: the case of the "states and properties of matter" in two Greek curricula. Review of Science, Mathematics and ICT Education, 4(2), 29-42.

Walan, S. (2019). Teaching children science through storytelling combined with hands-on activities-a successful instructional strategy?. Education 3-13, 47(1), 34-46.

Wightman, S. K., \& Roney, R. C. (2013). The effects of story performance on fifth-grade students' comprehension of narrative texts. Storytelling, Self, Society, 9(1), 20-52.

Yin, R.K. (1984) Case study research - design and methods. Sage Publications. Beverly Hills.

Zazkis, R., \& Liljedahl, P. (2009). Creating a story. In Teaching Mathematics as Storytelling (pp. 85-99). Brill Sense.

Zazkis, R., Liljedahl, P., \& Sinclair, N. (2009). Lesson plays: Planning teaching versus teaching planning. For the Learning of Mathematics, 29(1), 40-47. 